Artikel Penelitian

\title{
Perbandingan Tingkat Pengembalian Kredit Lembaga Perkreditan Desa (LPD) pada Mayoritas Penduduk yang Bekerja di Sektor Jasa Pertanian (Studi Kasus di Kabupaten Gianyar)
}

Ni Wayan Nita Agustini1 ${ }^{1}$ Ketut Budi Susrusa2 ${ }^{2}$, Gede Mekse Korri Arisena ${ }^{3}$

1,2,3 Program Studi Agribisnis Fakultas Pertanian Universitas Udayana, Jl. Panglima Besar Sudirman Kec. Denpasar Barat, Bali, Indonesia corresponding author. nitaagustini64@gmail.com

\begin{tabular}{|c|c|}
\hline ARTICLE INFO & ABSTRACT \\
\hline $\begin{array}{l}\text { Article history } \\
\text { Received May 01, } 2020 \\
\text { Revised May } 30,2020 \\
\text { Accepted June } 18,2020 \\
\text { Published October } 01,2020 \\
\text { Keywords } \\
\text { credit repayment rates } \\
\text { agricultural sector LPD } \\
\text { service sector LPD }\end{array}$ & $\begin{array}{l}\text { The establishment of Lembaga Perkreditan Desa (LPD) in assisting rural } \\
\text { communities to improve economic efforts including through the Payangan District } \\
\text { LPD and the LPD District of Gianyar, Bali. LPD always prioritizes and considers } \\
\text { aspects of efficiency and productivity, one of which is by channeling funds (credit). } \\
\text { This study was conducted to determine the distribution of loans by sector in terms of } \\
\text { the number of customers and the size of the loan and the comparison of the rate of } \\
\text { repayment of credit in the LPD in Payangan District and LPD in the Gianyar district. } \\
\text { The sampling technique in this study was carried out by census, and obtained } 33 \text { LPD } \\
\text { in Payangan District and } 39 \text { LPD in Gianyar District. The analysis technique used is } \\
\text { the Mann-Whitney Test (U-Test) analysis. The results showed that there was no } \\
\text { difference in the rate of return of credit between LPDs in Payangan District based on } \\
\text { the agricultural sector and LPDs in Gianyar District based on the service sector. } \\
\text { Through this research, LPDs whose credit repayment rates are still below } 80 \% \text { should } \\
\text { further tighten their selection of credit so that they do not become problem loans so } \\
\text { they can benefit from the loans extended by the LPD. }\end{array}$ \\
\hline
\end{tabular}

Copyright $\odot$ 2020, Agustini et al This is an open access article under the CC-BY-SA license

\section{PENDAHULUAN}

Pemerintah Provinsi Bali sebagai wadah daerah tujuan wisata terbesar di Indonesia yang terkenal dengan kultur budaya serta adat istiadatnya yang diatur dalam setiap desa pakraman tentunya diberikan hak otonomi untuk mengatur kehidupan sosial ekonomi masyarakatnya termasuk dalam hal mengatur potensi dan kekayaan desa adat. Melalui Surat Keputusan Gubernur Provinsi Bali No. 927 Tahun 1984 dibentuklah sebuah lembaga keuangan yang disebut Lembaga Perkreditan Desa (LPD) sebagai integrasi dari desa adat termasuk juga membantu masyarakat desa dalam meningkatkan usaha ekonomi. LPD berfungsi sebagai salah satu wadah kekayaan desa yang berupa uang atau surat-surat berharga lainnya, menjalankan fungsinya dalam bentuk usaha-usaha ke arah peningkatan taraf hidup krama desa dan dalam kegiatan usahanya banyak menunjang pembangunan desa (Darsana, 2010). Pembentukan LPD dilatar belakangi oleh terbatasnya modal dan permodalan yang dimiliki oleh krama desa adat dalam menjangkau kredit-kredit kecil yang dibutuhkan 
masyarakat untuk menjalankan usahanya. LPD adalah nama bagi usaha simpan pinjam milik masyarakat desa pakraman (desa adat) yang berada di Provinsi Bali dan merupakan sarana perekonomian masyarakat desa (Sundarianingsih, 2014).

LPD sebagai Lembaga Keuangan Desa bergerak dalam usaha simpan pinjam, dimana produk jasa yang ditawarkan oleh LPD dalam usahanya yaitu melalui tabungan, deposito dan pinjaman dari masyarakat yang kemudian disalurkan dalam bentuk pemberian kredit yang efektif. Penyaluran dana dalam bentuk kredit memiliki peranan yang cukup penting dalam perekonomian negara, dimana kredit memungkinkan masyarakat untuk melakukan investasi, distribusi, dan juga konsumsi barang dan jasa mengingat kelancaran kegiatan tersebut tidak lain adalah kegiatan pembangunan perekonomian masyarakat (Abdullah, 2012).

Karmila (2013) menyataan kredit adalah semua jenis pinjaman yang harus dibayarkan kembali bersama bunganya oleh peminjam sesuai dengan perjanjian yang telah disepakati.Penyaluran dana juga berperan penting dalam menghasilkan keuntungan bagi bank karena pendapatan terbesar bank yang berupa pendapatan bunga diperoleh dari kegiatan penyaluran dana (Ismail, 2011). Tetapi hampir setiap lembaga keuangan memiliki kredit bermasalah, khususnya LPD (Lembaga Perkreditan Desa) yang berada di Kecamatan Gianyar dan Kecamatan Payangan. Kepala LPD sangat mengharapkan semua debitur bisa membayar kreditnya dengan lancar. Jika semua debitur bisa membayar kreditnya dengan lancar itu akan memberikan keuntungan kepada LPD, begitu juga sebaliknya jika banyak terdapat kredit bermasalah, LPD tersebut akan mengalami kerugian. Berdasarkan tingkat kolektibilitasnya atau tingkat pengembalian kreditnya, menurut Kasmir (2014) dapat dikelompokkan ke dalam 4 golongan yaitu kredit lancar, kredit kurang lancar, kredit diragukan, dan kredit macet.

Menurut data Badan Pusat Statistik Kabupaten Gianyar (2016), kecamatan yang mayoritas penduduknya bermata pencaharian di sektor pertanian dan pemerintahan/jasa adalah Kecamatan Payangan dan Kecamatan Gianyar. Jumlah penduduk di Kecamatan Payangan yang bekerja di sektor pertanian adalah sebanyak 15.053 $(52,7 \%)$ dan jumlah penduduk yang bekerja di sektor pemerintaha/jasa di Kecamatan Gianyar adalah sebanyak 15.676 (33,9\%). Data mata pencaharian penduduk di Kabupaten Gianyar tersedia ditabel lampiran satu. Berdasarkan data dari LPLPD Kabupaten Gianyar (2019) terdapat 33 LPD di Kecamatan Payangan dan terdapat 39 LPD di Kecamatan Gianyar yang tersebar di setiap desanya.

Masyarakat di Kecamatan Payangan dan Kecamatan Gianyar mengajukan kredit ke LPD yang ada di setiap desa untuk membantu menambah modal untuk mengembangkan bisnis atau usaha mereka. Seperti halnya baik perusahaan maupun masyarakat tujuan akhir dari pinjaman kredit itu adalah untuk memperoleh keuntungan, keuntungan yang diperoleh setiap perusahaan perbankan sebagian besar berasal dari bunga pinjaman yaitu sebagai hasil dari diberikannya sejumlah kredit kepada para nasabahnya atau debitur. Karena kredit adalah aset yang menghasilkan pendapatan bunga dari pengembaliannya, maka porsi kredit dalam aset perbankan sangatlah dominan jumlahnya. Selain itu tingkat pengembalian kredit juga dapat menggambarkan kondisi kredit bermasalah yang dapat mempengaruhi besarnya penyisihan untuk cadangan aktiva produktif dan berpengaruh juga pada modal lembaga keuangan itu sendiri. Begitu juga dengan LPD untuk menjaga kelangsungan usahanya, maka LPD menyediakan pemberian kredit untuk meningkatkan profitabilitasnya. Hal inilah yang menunjukkan bahwa penelitian ini penting untuk dilakukan.

Oleh sebab itu, pada penelitian ini peneliti ingin meneliti "Perbandingan Tingkat Pengembalian Kredit Pada Lembaga Perkreditan Desa Yang Dicirikan Kecamatan Mayoritas Penduduk Bekerja Di Sektor Pertanian Dengan Jasa Di Kabupaten Gianyar" dengan objek yang diteliti ialah Lembaga Perkreditan Desa (LPD) di Kecamatan Payangan dan Lembaga Perkreditan Desa (LPD) di Kecamatan Gianyar, Kabupaten Gianyar, Provinsi Bali. Penelitian ini bertujuan untuk mengetahui distribusi pinjaman berdasarkan sektor dari segi jumlah nasabah dan besarnya pinjaman dan perbandingan tingkat pengembalian kredit pada LPD di Kecamatan Payangan dan LPD di kecamatan Gianyar, Kabupaten Gianyar, Bali pada bulan Desember 2019.

\section{METODE PENELITIAN}

Penelitian ini dilakukan di Lembaga Perkreditan Desa (LPD) yang berlokasi di Kecamatan Payangan dan Lembaga Perkreditan Desa (LPD) yang berada di Kecamatan Gianyar, Kabupaten Gianyar, Bali. Lokasi ini dipilih karena Kecamatan Payangan merupakan Kecamatan yang mayoritas penduduknya bermata pencaharian pada sektor pertanian dan Kecamatan Gianyar merupakan kecamatan yang mayoritas penduduknya bermata pencaharian pada sektor jasa. Pengumpulan data dengan menggunakan metode dokumentasi dan studi kepustakaan.Sumber data yang digunakan dalam penelitian ini adalah data sekunder. Penentuan sampel dalam penelitian ini dilakukan dengan jenis Non Probability Sampling. Teknik pengambilan 
sampel dengan menggunakan metode sensus. Sensus adalah kegiatan mengumpulkan data dan informasi dengan cara mengamati seluruh elemen dari populasi atau metode penarikan sampel bila semua anggota populasi dijadikan sebagai sampel. Menurut Kristanto (2018) sampel adalah bagian dari populasi yang dijadikan subjek penelitian sebagai "wakil" dari para anggota populasi.

Analisis data yang dilakukan meliputi :

Penelitian ini menggunakan alat bantu uji statistik dalam mengolah data. Dalam penelitian ini menggunakan beberapa jenis analisis. Untuk lebih mempermudah, analisis data di rinci berdasarkan tujuan penelitian. Berikut rinciannya :

Analisis tujuan satu digunakan untuk menganalisis distribusi pinjaman berdasarkan sektor dari segi jumlah nasabah dan besarnya pinjaman pada LPD di Kecamatan Payangan dan Kecamatan Gianyar. Analisis tujuan satu menggunakan Analisis Deskriptif kualitatif. Analisis deskriptif digunakan untuk menganalisis data dengan cara menggambarkan data yang telah terkumpul sebagaimana adanya tanpa bermaksud membuat kesimpulan yang berlaku untuk umum atau generalisasi (Sugiyono, 2012). Analisis deskriptif kualitatif digunakan untuk mengetahui distribusi pinjaman berdasarkan sektor dari segi jumlah nasabah dan besarnya pinjaman pada LPD di Kecamatan Payangan dan Kecamatan Gianyar.

Analisis tujuan dua digunakan untuk menjawab perbandingan tingkat pengembalian kredit pada LPD di Kecamatan Payangan dan LPD di kecamatan Gianyar. Analisis yang digunakan adalah Uji Mann - Whitney (UTest) atau U-test. Uji Mann - Whitney (U-Test) atau U-test digunakan untuk menguji signifikansi hipotesis komparatif dua sampel independen bila datanya berbentuk ordinal. U-test dalam penelitian ini akan digunakan untuk membandingkan tingkat pengembalian kredit pada LPD Kecamatan Payangan dengan LPD Kecamatan Gianyar. Terdapat rumus yang digunakan untuk pengujian. Rumus tersebut digunakan dalam perhitungan untuk mengetahui harga $U$ mana yang lebih kecil. Harga $U$ yang lebih kecil tersebut yang digunakan untuk pengujian dan membandingkan dengan $U$ tabel (Sugiyono, 2017). Nilai $U$ dihitung menggunakan rumus sebagai berikut jika sampel kurang dari 20.

U_1 =n_1 n_2+ (n_1 (n_1+1))/2-R_1

U_2=n_1 n_2+ (n_2 (n_2+1))/2-R_2

Keterangan:

$\mathrm{n} 1=$ Jumlah sampel 1

n2 = Jumlah sampel 2

$\mathrm{U} 1=$ Jumlah peringkat 1

$\mathrm{U} 2=$ Jumlah peringkat 2

$\mathrm{R} 1=$ Jumlah rangking pada sampel $\mathrm{n} 1$

$\mathrm{R} 2$ = Jumlah rangking pada sampel n2

Menentukan diterima atau ditolaknya hipotesis maka pada Uji Mann - Whitney (U-Test) dapat dilihat dengan kriteria sebagai berikut.

H0 diterima bila $U$ hitung $\geq U$ tabel $(\alpha ; n 1, n 2)$

$\mathrm{H} 0$ ditolak bila $U$ hitung $\leq \mathrm{U}$ tabel $(a ; n 1, n 2)$

Jika sampel lebih dari 20 maka berikut rumus yang dapat digunakan. Rumus ini digunakan untuk membandingkan angka $z$ hitung dan $z$ tabel. Rumus mencari z hitung sebagai berikut.

$$
Z=\left(U-\left(1 / 2 \times n_{-}(1) \times n \_(2)\right)\right) / \sqrt{ }\left(1 \times n_{-}(1) \times n_{-}(2) \times\left(n_{-}(1)+n_{-}(2)+1\right)\right)
$$

\section{HASIL DAN PEMBAHSAN}

\section{Distribusi Pinjaman Berdasarkan Sektor Dari Segi Jumlah Nasabah Dan Besarnya Pinjaman Pada LPD Di Kecamatan Payangan Dan Kecamatan Gianyar}

Berdasarkan data laporan bulanan seluruh LPD di Kecamatan Payangan dan Kecamatan Gianyar bulan Desember tahun 2019, distribusi pinjaman berdasarkan sektor dari segi jumlah nasabah dan besarnya pinjaman pada LPD di Kecamatan Payangan dan Kecamatan Gianyar ialah sebagai berikut. 
Tabel 1. Distribusi Pinjaman Berdasarkan Sektor di Kecamatan Payangan

\begin{tabular}{lcccc}
\hline \multicolumn{1}{c}{ Nama Sektor } & $\begin{array}{c}\text { Jumlah } \\
\text { LPD }\end{array}$ & Minimum & Maximum & Total \\
\hline $\begin{array}{l}\text { Pertanian } \\
\text { (orang) }\end{array}$ & 33 & 21 & 1.385 & 5.990 \\
$\begin{array}{l}\text { Pertanian } \\
\text { (Pinjaman Rp.) }\end{array}$ & 33 & 112.306 .000 & 9.254 .009 .000 & 58.550 .998 .530 \\
$\begin{array}{l}\text { Peternakan } \\
\text { (orang) }\end{array}$ & 15 & 1 & 187 & 617 \\
$\begin{array}{l}\text { Peternakan } \\
\text { (Pinjaman Rp.) }\end{array}$ & 15 & 5.500 .000 & 2.788 .617 .000 & 7.229 .462 .000 \\
$\begin{array}{l}\text { Perdagangan } \\
\text { (orang) }\end{array}$ & 28 & 5 & 421 & 1.578 \\
$\begin{array}{l}\text { Perdagangan } \\
\text { (Pinjaman Rp.) }\end{array}$ & 28 & 17.399 .000 & 5.118 .000 .000 & 19.567 .926 .770 \\
$\begin{array}{l}\text { Industri } \\
\text { (orang) }\end{array}$ & 8 & 6 & 80 & 231 \\
$\begin{array}{l}\text { Industri } \\
\text { (Pinjaman Rp.) }\end{array}$ & 8 & 34.750 .000 & 2.832 .433 .000 & 5.920 .789 .000 \\
$\begin{array}{l}\text { Perkebunan } \\
\text { (orang) }\end{array}$ & 7 & 7 & 34 & 169 \\
$\begin{array}{l}\text { Perkebunan } \\
\text { (Pinjaman Rp.) }\end{array}$ & 7 & 20.820 .000 & 231.886 .000 & 999.437 .000 \\
$\begin{array}{l}\text { Jasa } \\
\text { (orang) }\end{array}$ & 30 & 6 & 803 & 4.455 \\
$\begin{array}{l}\text { Jasa } \\
\text { (Pinjaman Rp.) }\end{array}$ & 30 & 22.729 .000 & 8.481 .463 .000 & 45.189 .212 .910 \\
\hline
\end{tabular}

Sumber : Data Sekunder LPD Sekecamatan Payangan 2019

Berdasarkan Tabel 1 diketahui bahwa dari 33 LPD yang berada di Kecamatan Payangan distribusi pinjaman berdasarkan sektor dari segi jumlah nasabah dan besarnya pinjaman yang disalurkan oleh LPD pada bulan Desember 2019 terdapat sektor pertanian, sektor peternakan, sektor perdagangan, sektor industri, sektor perkebunan, dan sektor jasa. Berdasarkan data yang didaptakan, dari 33 LPD yang ada di Kecamatan Payangan semuanya memiliki debitur dari sektor pertanian, minimun jumlah debitur dari sektor pertanian yaitu 21 orang, maksimun debiturnya 1.385 orang, dan total debitur dari sektor pertanian pada LPD di Kecamatan Payangan yaitu 5.590 orang. Pada sektor pertanian dari 33 LPD diketahui sebesar Rp.112.306.000 sebagai nilai pinjaman terkecil, nilai pinjaman terbesarnya Rp.9.254.009.000, dan total pinjaman yang disalurkan untuk sektor pertanian di LPD Kecamatan Payangan adalah sebesar Rp58.550.998.530.

Dari 33 LPD yang ada di Kecamatan Payangan, hanya 30 LPD yang memiliki debitur di sektor jasa, minimun jumlah debitur dari sektor jasa yaitu 6 orang, maksimun debiturnya 803 orang, dan total debitur dari sektor jasa pada LPD di Kecamatan Payangan adalah 4.455 orang. Pada sektor jasa dari 30 LPD diketahui sebesar Rp.22.729.000 sebagai nilai pinjaman terkecil, nilai pinjaman terbesarnya Rp.8.481.463.000, dan total pinjaman yang disalurkan untuk sektor jasa di LPD Kecamatan Payangan adalah sebesar Rp45.189.212.910. Dari 6 sektor yang ada pada LPD di Kecamatan Payangan debitur yang paling banyak terdapat pada sektor pertanian sedangkan yang paling sedikit terdapat pada sektor perkebunan yang berjumlah 169 debitur dari 33 LPD yang berada di Kecamatan Payangan. 
Tabel 2. Distribusi Pinjaman Berdasarkan Sektor di Kecamatan Gianyar

\begin{tabular}{|c|c|c|c|c|}
\hline Nama Sektor & $\begin{array}{l}\text { Jumlah } \\
\text { LPD }\end{array}$ & Minimum & Maximum & Total \\
\hline $\begin{array}{l}\text { Pertanian } \\
\text { (orang) }\end{array}$ & 35 & 1 & 367 & 1.981 \\
\hline $\begin{array}{l}\text { Pertanian } \\
\text { (Pinjaman Rp.) }\end{array}$ & 35 & 12.346 .106 & 3.692 .218 .000 & 22.715 .481 .520 \\
\hline $\begin{array}{l}\text { Perikanan } \\
\text { (orang) }\end{array}$ & 2 & 1 & 156 & 157 \\
\hline $\begin{array}{l}\text { Perikanan } \\
\text { (Pinjaman Rp.) }\end{array}$ & 2 & 782.000 & 5.086 .000 .000 & 5.086 .782 .000 \\
\hline $\begin{array}{l}\text { Peternakan } \\
\text { (orang) }\end{array}$ & 16 & 1 & 478 & 1.063 \\
\hline $\begin{array}{l}\text { Peternakan } \\
\text { (Pinjaman Rp.) }\end{array}$ & 16 & 20.999 .500 & 2.700 .752 .000 & 7.823 .510 .928 \\
\hline $\begin{array}{l}\text { Perdagangan } \\
\text { (orang) }\end{array}$ & 36 & 2 & 559 & 2.769 \\
\hline $\begin{array}{l}\text { Perdagangan } \\
\text { (Pinjaman Rp.) }\end{array}$ & 36 & 1.000 .000 & 10.678 .613 .000 & 49.897 .038 .000 \\
\hline $\begin{array}{l}\text { Industri } \\
\text { (orang) }\end{array}$ & 21 & 1 & 159 & 680 \\
\hline $\begin{array}{l}\text { Industri } \\
\text { (Pinjaman Rp.) }\end{array}$ & 21 & 500.000 & 2.771 .011 .000 & 12.909 .861 .400 \\
\hline $\begin{array}{l}\text { Perkebunan } \\
\text { (orang) }\end{array}$ & 3 & 13 & 41 & 88 \\
\hline $\begin{array}{l}\text { Perkebunan } \\
\text { (Pinjaman Rp.) }\end{array}$ & 3 & 28.045 .000 & 878.865 .000 & 1.003 .392 .000 \\
\hline $\begin{array}{l}\text { Kerajinan } \\
\text { (orang) }\end{array}$ & 4 & 21 & 360 & 4.455 \\
\hline $\begin{array}{l}\text { Kerajinan } \\
\text { (Pinjaman Rp.) }\end{array}$ & 4 & 335.711 .000 & 5.908 .688 .000 & 7.771 .951 .000 \\
\hline $\begin{array}{l}\text { Jasa } \\
\text { (orang) }\end{array}$ & 39 & 4 & 1.071 & 7.421 \\
\hline $\begin{array}{l}\text { Jasa } \\
\text { (Pinjaman Rp.) }\end{array}$ & 39 & 12.500 .000 & 65.935 .630 .000 & 304.312 .821 .100 \\
\hline
\end{tabular}

Sumber : Data Sekunder LPD Sekecamatan Gianyar 2019

Berdasarkan Tabel 2 diketahui bahwa dari 39 LPD yang berada di Kecamatan Gianyar distribusi pinjaman berdasarkan sektor dari segi jumlah nasabah dan besamya pinjaman yang disalurkan oleh LPD pada bulan Desember 2019 terdapat sektor pertanian, sektor perikanan, sektor peternakan, sektor perdagangan, sektor industri, sektor perkebunan, sektor kerajinan, dan sektor jasa. Berdasarkan data yang didaptakan, dari 39 LPD yang ada di Kecamatan Gianyar semuanya memiliki debitur di sektor jasa, minimun jumlah debitur dari sektor jasa yaitu 4 orang, maksimun debiturnya 1.071 orang, dan total debitur dari sektor jasa pada LPD di Kecamatan Gianyar yaitu 1.981 orang. Pada sektor pertanian dari 39 LPD diketahui sebesar Rp. 12.500 .000 sebagai nilai pinjaman terkecil, nilai pinjaman terbesarnya Rp. 65.935 .630 .000 , dan total pinjaman yang disalurkan untuk sektor jasa di LPD Kecamatan Payangan adalah sebesar Rp.304.312.821.100.

Dari 39 LPD yang ada di Kecamatan Gianyar, hanya 35 LPD yang memiliki debitur di sektor pertanian, minimun jumlah debitur dari sektor pertanian yaitu 1 orang, maksimun debiturnya 367 orang, dan total debitur dari sektor pertanian pada LPD di Kecamatan Payangan adalah 1.981 orang. Pada sektor pertanian dari 30 LPD diketahui sebesar Rp. 12.346.106 sebagai nilai pinjaman terkecil, nilai pinjaman terbesarnya Rp. 3.692.218.000, dan total pinjaman yang disalurkan untuk sektor pertanian di LPD Kecamatan Gianyar adalah

54 
sebesar Rp. 22.715.481.520. Dari 8 sektor yang ada pada LPD di Kecamatan Gianyar debitur yang paling banyak terdapat pada sektor jasa sedangkan yang paling sedikit terdapat pada sektor perkebunan yang berjumlah 88 debitur dari 39 LPD yang berada di Kecamatan Payangan.

Jika dilihat dari jumlah LPD, sektor pertanian memang lebih banyak terdapat pada LPD di Kecamatan Gianyar tetapi jika dilihat dari jumlah debitur dan jumlah total pinjaman maka lebih banyak terdapat pada LPD yang berada di Kecamatan Payangan. Begitu juga dengan sektor jasa, kalau dilihat dari jumlah LPD, jumlah debitur, dan jumlah total pinjaman, lebih banyak terdapat pada LPD di Kecamatan Gianyar dibandingkankan dengan LPD yang ada di Kecamatan Payangan. Berbeda dengan penelitian yang dilakukan Virgantini, (2019) distribusi dana kredit yang diberikan LPD Desa Adat Palaktiying kepada responden pada ekonomi pedesaan selama tiga tahun terakhir yaitu terbagi menjadi enam jenis sektor perekonomian dengan persentase tertinggi yaitu sektor peternakan 50,16 . Persentase terendah yaitu sebesar $0,3 \%$ terdapat pada sektor perdagangan, upacara agama, dan kebutuhan konsumsi. Penelitian yang dilakukan oleh Damayanti, (2019) pada LPD Desa Adat Penatih juga menunjukkan hasil distribusi penyaluran kredit paling banyak yaitu ke sektor peternakan, sedangkan rata-rata besar pinjaman responden pada penelitian ini adalah Rp 18.937.500,00.

\section{Tingkat Pengembalian Kredit Pada LPD Di Kecamatan Payangan Dan LPD Kecamatan Gianyar Menggunakan Uji Mann Whitney}

Uji Mann - Whitney (U-Test) atau U-test dalam penelitian ini digunakan untuk membandingkan tingkat pengembalian kredit pada LPD di Kecamatan Payangan dan LPD Kecamatan Gianyar. Hasil pengujian dapat dilihat pada tabel 5.9 dan 5.10 sebagai berikut.

Tabel 3. Peringkat (Ranks) Tingkat Pengembalian Kredit

\begin{tabular}{lllcc}
\hline \multicolumn{1}{c}{ Kecamatan } & N & Mean Ranks & Sum Of Ranks \\
\hline TPK LPD & Payangan & 33 & 34,59 & 1141,50 \\
& Gianyar & 39 & 38,12 & 1486,50 \\
& Total & 72 & & \\
\hline
\end{tabular}

Sumber : Output tools SPSS 2020

Berdasarkan Tabel 3 dapat diketahui bahwa rata-rata peringkat atau skor (Mean Rank) tingkat pengembalian kredit pada LPD di Kecamatan Gianyar lebih tinggi dari Mean Rank tingkat pengembalian kredit pada LPD di Kecamatan Payangan. Rata-rata skor tingkat pengembalian kredit pada LPD di Kecamatan Gianyar sebesar 38,12 sedangkan pada LPD di Kecamatan Payangan sebesar 34,59. Dengan demikian, ini menunjukkan bahwa tingkat pengembalian kredit pada LPD di Kecamatan Gianyar lebih baik dari pada tingkat pengembalian kredit pada LPD di Kecamatan Payangan.

Tabel 4. Uji Statistik Tingkat Pengembalian Kredit

\begin{tabular}{lc}
\hline & TPK LPD \\
\hline Mann-Whitney & 580,500 \\
Wilcoxom W & 1141,500 \\
Z & $-0,712$ \\
Asymp.Sig.(2-tailed) & 0,476 \\
\hline
\end{tabular}

Sumber : Output tools SPSS 2020

Berdasarkan tabel 4 dapat dilihat bahwa 0,476 > 0,05 maka H0 diterima dan $\mathrm{H} 1$ ditolak, dapat ditarik kesimpulan tidak ada perbedaan tingkat pengembalian kredit antara LPD di Kecamatan Payangan yang berbasis pada sektor pertanian dengan LPD di Kecamatan Gianyar yang berbasis pada sektor jasa. Artinya tingkat pengembalian kredit pada LPD di Kecamatan Gianyar dan tingkat pengembalian kredit pada LPD di Kecamatan Payangan sama. Hal ini terjadi karena karakteristik nasabah yang memiliki ciri khas sendiri-sendiri, di daerah payangan memang unggul dan mempunyai pengalaman usaha di sektor pertanian sedangkan daerah Gianyar unggul dan mempunyai pengalaman usaha di sektor jasa. Pengalaman usaha di sektor pertanian yang dimiliki debitur pada LPD Kecamatan Payangan dan pengalaman usaha di sektor jasa yang 
dimiliki debitur pada LPD Kecamatan Gianyar sangat mempengaruhi kemampuan debitur untuk mengelola kegiatannya sehingga dapat menghasilkan dana untuk membayar kewajibannya kepada LPD.

Hasil penelitian Arinta, (2014) menyatakan pengalaman usaha yang semakin lama akan mempengaruhi kemampuan seseorang dalam mengelola usaha dan menghindari risiko yang menyebabkan kegagalan. Pengalaman usaha yang semakin lama meningkatkan pemahaman kemampuan debitur dalam mengelola usahanya sehingga mendukung keberhasilan usaha. Keberhasilan usaha tersebut dapat menjamin perolehan pendapatan atau keuntungan sebagai sumber biaya hidup serta memberikan peluang kemampuan membayar kredit secara lancar.

Penyebab tidak adanya perbedaan tingkat pengembalian kredit pada LPD di Kecamatan Payangan dan Kecamatan Gianyar juga disebabkan karena terdapat jaminan dan awig-awig desa pekraman yang mengatur tentang kebijakan LPD. Jaminan kredit merupakan sumber pembayaran kedua, apabila debitur tidak mampu membayar kembali kredit, harta debitur yang dijadikan jaminan akan di eksekusi, hasil penjualannya digunakan untuk membayar kembali kredit. Peran awig-awig tidak hanya sebatas mengatur krama dalam kehidupan bermasyarakat, namun kini awig-awig juga mengatur mengenai lembaga-lembaga yang berada di bawah naungan desa pekraman seperti LPD. LPD masih menggunakan awig-awig sebagai pedoman dalam melaksanakan kegiatan operasionalnya, dengan maksud dan tujuan agar mampu mengikat seluruh krama yang membutuhkan dana agar tidak melanggar aturan yang telah disepakati. Pemanfaatan awig-awig pada LPD bertujuan untuk menekan tingkat kredit macet yang terjadi.

\section{KESIMPULAN}

Distribusi pinjaman berdasarkan sektor dari segi jumlah nasabah dan besarnya pinjaman yang tertinggi pada LPD di Kecamatan Payangan berada pada sektor pertanian dan di Kecamatan Gianyar berada pada sektor jasa sedangkan untuk sektor terendah sama-sama berada pada sektor perkebunan. Tidak ada perbedaan yang signifikan (nyata) mengenai tingkat pengembalian kredit antara LPD di Kecamatan Payangan yang berbasis pada sektor pertanian dengan LPD di Kecamatan Gianyar yang berbasis pada sektor jasa karena sebagaian besar debitur sudah membayar kreditnya dengan lancar.

\section{DAFTAR PUSTAKA}

Abdullah, T. (2012). Bank dan Lembaga Keuangan. Jakarta: Rajawali Pers.

Arifin, J. (2017). SPSS 24 untuk Penelitian dan Skripsi. Jakarta: Kelompok Gramedia.

Arinta, D. Y. (2014). Pengaruh Karakteristik Individu, Karakteristik Usaha, Karaktersitik Kredit Terhadap Kemampuan Debitur Membayar Kredit Pada BPR Jatim Cabang Probolinggo (Studi Pada Nasabah UMKM Kota Probolinggo). 2, 1-16.

Badan Pusat Statistik Kabupaten Gianyar (2016)

Damayanti, N. P. E. P. (2019). Peran Lembaga Perkreditan Desa (LPD) Dalam Penyaluran Kredit Pertanian Di Desa Adat Penatih, Kecamatan Denpasar Timur, Kota Denpasar.

Ida Bagus Darsana. (2010). Peranan Dan Kedudukan LPD Dalam Sistem Perbankan Di Indonesia (K. Wicaksana, ed.).

Ismail. (2011). Manajemen Perbankan. Jakarta: Kencana.

Karmila. (2013). Kredit Bank Edisi Kedua (Kedua; F. dan L. S. Puspitasari, ed.). Sleman: PT Intan Sejati Klaten.

Kasmir. (2014). Manajemen Perbankan. Jakarta: PT. Raja Grafindo Persada.

Kristanto, V. H. (2018). Metodelogi Penelitian Pedoman Penulisan Karya Tulis IImiah (KTI). Yogyakarta: Deepublish.

Lembaga Pemberdayaan Lembaga Perkreditan Desa Kabupaten Gianyar. 2019.

56

Nita Agustini et.al (Perbandingan Tingkat Pengembalian, credit repayment rates, agricultural sector LPD, senvice sector LPD) 
Sugiyono. (2012). Metode Penelitian Kuantitatif, Kualitatif dan R\&D. Bandung: Alfabeta.

Sugiyono. (2017). Metode Penelitian Bisnis. Bandung: Alfabeta Bandung.

Sundarianingsih, P. (2014). Dalam Menggerakkan Sosial Ekonomi Masyarakat Pedesaan (Studi Pada Lembaga Perkreditan Desa (LPD) Desa Adat Pekutatan). Jurnal Ekonomi Pembangunan, 12(1), 69.

Virgantini, Ni Luh Eka. 2019. Proporsi Penggunaan Dana Lembaga Perkreditan Desa (LPD) Pada Sektor Pertanian (Studi Kasus Lpd Desa Adat Palaktiying, Kecamatan Bangli, Kabupaten Bangli). Skripsi. Program Studi Agribisnis, Fakultas Pertanian, Universitas Udayana. 